\title{
Corporate Governance and Earnings Management: Evidence from Canada
}

\author{
Yoser Gadhoum \\ Institute of Strategic Studies on Governance, Former Dean of Research and Graduate Studies, Prince Mohamad Bin Fahd \\ University (PMU), Al Khobar, KSA \\ Email: gadhoum.yoser@gmail.com
}

How to cite this paper: Gadhoum, Y. (2021). Corporate Governance and Earnings Management: Evidence from Canada. Journal of Financial Risk Management, 10, 516-544.

https://doi.org/10.4236/jfrm.2021.104027

Received: November 18, 2021

Accepted: December 26, 2021

Published: December 29, 2021

Copyright $\odot 2021$ by author(s) and Scientific Research Publishing Inc. This work is licensed under the Creative Commons Attribution International License (CC BY 4.0). http://creativecommons.org/licenses/by/4.0/

\begin{abstract}
This paper investigates the relation between corporate governance and earnings management in the Canadian setting characterized by ownership concentration in the hands of large shareholders and a separation between ownership and control. We find that earnings management decreases with the level of cash flow rights of the largest ultimate owner and increases with the magnitude of separation between its control and cash flow rights. Earnings management is higher in firms controlled through pyramidal structures and multiple classes of shares, and lower in firms where there is a second ultimate owner with sufficient bargaining power vis-à-vis the largest ultimate owner. Finally, earnings management is higher in family controlled firms. Our results highlight the importance of firm-specific corporate governance in determining earnings management.
\end{abstract}

\section{Keywords}

Earnings Management, Ownership Structure, Corporate Governance, Accruals

\section{Introduction}

A large body of research has addressed the discretion exercised by U.S managers in reporting accounting numbers ${ }^{1}$. Under Generally Accepted Accounting Principles (G.A.A.P), managers are provided with some flexibility in financial reporting. As a result, self-interested managers may be tempted to distort ac-

${ }^{1}$ See Healy and Whalen (1999); Makarem and Roberts (2020); and Kontesa, Brahmana and Tong (2021) for an extensive literature review. 
counting performance at the expense of outside shareholders' interests.

Unlike the U.S where corporate ownership structure is dispersed with professional managers having control, ownership is concentrated in the hands of large (controlling) shareholders elsewhere around the world (La Porta et al., 1999). Moreover, large shareholders, mostly families, often achieve control beyond cash flow rights using pyramidal structures, cross-holdings and multiple classes of shares. Since corporate governance features outside the U.S are markedly different, it is likely that earnings management incentives are also different. However, little work has been done to examine the effects of corporate governance on earnings management outside the U.S.

This paper contributes to the literature by investigating the impact of corporate governance on earnings management in a large sample of Canadian firms. Canada offers an ideal laboratory to explore this issue. Canadian G.A.A.P are close to U.S G.A.A.P, yet Canadian corporate governance is different in that ownership is concentrated in the hands of large shareholders, generally families, that are often able to lever up their control rights over cash low rights.

To do so, we use unsigned discretionary accruals as a proxy for earnings management and relate it to ultimate ownership variables in Canada during the period 1995-1997. We hypothesise that ultimate owners have two distinct effects on earnings management. The first effect is associated with the level of their cash flow rights. Because any adverse effects of earnings management, such as the market readjustment of share price, have a direct impact on ultimate owner's holding, we expect ultimate owners to reduce earnings management as their share of cash flow rights increases. The second effect is linked to the separation between cash flow and control rights. If ultimate owners achieve a separation between ownership and control, then their incentives will be distorted toward extracting private benefits since they internalize only a faction of the effects of their actions. Such private benefits include tunnelling of assets, opportunistic transfer pricing between controlled firms, expropriation of corporate opportunities, creeping acquisitions, etc. In turn, ultimate owners may want to engage in earnings management as a way to camouflage their private benefits. Consistent with our hypotheses, we find that unsigned discretionary accruals are negatively related to the level of the largest ultimate owner's cash flow rights. At the same time, our results show that unsigned discretionary accruals are higher in firms controlled through pyramidal structures and multiple classes of shares. Also unsigned discretionary accruals are positively related to the magnitude (especially at higher levels) of the separation between ownership and control. We also focus on the presence and the bargaining power of a second ultimate owner as a mean to inhibit the largest ultimate owner incentives to manage earnings arising from the separation between ownership and control. Our results show that the bargaining power, but not the presence, of a second ultimate owner has a negative effect on unsigned discretionary accruals. Finally, we study earnings management in family-controlled firms. Corporate governance of family firms is likely 
to be different than that of other firms because families are thought to generate extra private benefits of control such as amenities and political connections and to build a reputation. Therefore, we hypothesise that the different governance of family firms may induce families to undertake more earnings management. For instance families may manipulate earnings to mask their extra private benefits and to safeguard their reputation. Consistent with our hypothesis, we find that unsigned discretionary accruals are higher in family controlled firms.

This paper adds to the recent literature examining the consequences of the separation between ownership and control. Controlling shareholders that lever their voting rights over cash flow rights may have objectives other than value maximization. Claessens, Djankov, Fan and Lang (2002), Lins (2003) and Attig, Fischer and Gadhoum (2003) find evidence that the separation between ownership and control have a negative impact on firm performance. The evidence in this paper suggests another effect of the separation between ownership and control: controlling shareholders not only adversely affect delivered performance, they also manipulate it. As such, an implication of our evidence is that the costs associated with the separation between ownership and control may be larger than previously documented.

This study contributes to the literature investigating the role of certain governance mechanisms in monitoring opportunistic earnings management. Xie, Davidson and DaDalt III (2003); Klein (2002); Chung, Firth and Kim (2002); Badolato, Donelson and Ege (2014); and Alharbi, Mamum and Atawnah (2021) examine the role of audit committee, board of directors and institutional shareholdings and find evidence that they reduce opportunistic earnings management. In this paper, we argue that such governance mechanisms may fail in an environment dominated by large shareholders and propose an alternative governance device, namely a second ultimate owner that is likely to curb earnings management. The evidence in this paper shows that a second ultimate with sufficient bargaining power vis-à-vis the largest ultimate owner is able to reduce opportunistic earnings management.

This study also contributes to the literature on the role of families as controlling shareholders. Morck, Strangeland and Yeung (2000); and Gadhoum (2015) depict a too pessimistic view of family ownership in Canada that they term it the "Canadian disease". The authors argue that families have preferential access to capital, enhanced lobbying power and are less likely to spend on innovation. They find that economies dominated by family firms exhibit low growth and conclude that family ownership is socially undesirable. In this paper, we find evidence that families distort the flow of information to outsiders through higher earnings management so that one might not assess accurately the actual cost related to family ownership.

The reminder of this paper is organized as follows. In Section 2, we review the literature and develop testable hypotheses. In Section 3, we describe the data and present descriptive statistics of our variables in Section 4. We conclude the paper 
in Section 5.

\section{Literature Review and Hypotheses Development}

\subsection{Earnings Management}

Earnings management is the practice of distorting the underlying accounting performance of the firm ${ }^{2}$. Under Generally Accepted Accounting Principles (GAAP), managers are provided with some flexibility in reporting accounting numbers. Managers might choose among a multitude of accounting methods to report a given transaction. For instance, to report inventories and cost of goods sold, managers have the choice between the FIFO, LIFO or weighted average inventory cost methods. Further, they have to make predictions of future events that impact actual accounting numbers such as the salvage value of property, plant and equipment and the amount of uncollected receivables. Finally, managers have the ability to time some expenses and revenues. For example, they have the discretion to accelerate (postpone) expenses such as R\&D and advertising expenditures, or revenues by altering the terms of their firm's receivable policy.

The aforementioned managerial flexibility in financial reporting is justified in part by the desire of standard setters to make accounting numbers reflect more closely the true economic conditions of the firm. However, it may be a double-edged sword, as managers may use it for self-interested reasons. Indeed, there is mounting evidence that document that managers engage in opportunistic earnings management. First, managers are found to "window-dress" financial statements prior or during specific events. The evidence shows that managers "overstate" earnings before initial public offerings (Teoh, Welch and Wong, 1998a), seasoned equity offerings (Rangan, 1998; Teoh, Welch and Wong, 1998b), stock-for-stock mergers (Erickson and Wang, 1999; Louis, 2004), and during hostile bids (Easterwood, 1997) and proxy contests (DeAngelo, 1988; Alharbi, Atawnah, Al Mamun and Jahangir, 2020). On the other side, managers are found to "understate" earnings prior management buyouts (Perry and Williams, 1994) ${ }^{3}$. Second, there is an evidence that managers manipulate earnings to meet some specific targets. For example, managers are found to manage reported earnings to avoid earnings decreases and losses (Burgstahler and Dichev, 1999; Baker, Lopez, Reienga and Rush, 2019), to meet their forecasts (Kasznik,

${ }^{2}$ Healy and Whalen (1999) propose a more formal definition of earnings management: "Earnings management occurs when managers use judgement in financial reporting and in structuring transactions to alter financial reports to either mislead some stakeholders about the underlying economic performance of the company, or to influence contractual outcomes that depend on reported accounting numbers".

${ }^{3}$ Artificially increasing (decreasing) earnings is directed to paint a favorable (unfavorable) picture of the firm leading outsiders to be overly optimistic (pessimistic) about the prospects of the firm. Therefore, overstating earnings before an equity issue overvalues the issue price and increases the proceed in managerial hands (Jones, 2018). During hostile bids and proxy contests, overstating earnings makes shareholders more likely to vote against the change in control. Conversely, understating earnings before a management buyout depresses share prices and thus minimizes managerial disbursement to take the firm private. 
1999), and financial analysts' forecasts (Payne and Robb, 2000). Third, the evidence indicates that managers manage earnings to maximize their compensation. Healy (1985) and Holthausen, Larcker, \& Sloan (1995); and Kama and Melumad (2020) find that when earnings rise above the upper bound of their bonus plan, managers are more likely to understate actual earnings ${ }^{4}$. Understating actual earnings does not change the amount of the bonus but defers earnings to future years so that the probability of gleaning future bonuses is higher. Thus, these results are consistent with an intertemporal maximization of the bonus award stream. Fourth, theoretical and empirical work suggests that managers have an incentive to smooth reported earnings. Fudenberg and Tirole (1995) develop a model where managers derive non-pecuniary benefits from running their firms and their job security depends on reported earnings. The model predicts that managers will understate earnings in good times and overstate earnings in bad times. Consistent with the Fudenberg and Tirole model, Defond and Park (1997); Ahmed, Lobo and Zhou (2000); Baker, Lopez, Reienga and Rush (2019); and Kontesa, Brahmana and Tong (2021) find that firms having high (low) performance understate (overstate) earnings when expected future performance is low (high).

\subsection{Ownership Concentration and the Separation between Ownership and Control}

In light of the evidence above, earnings management may be viewed as an agency cost of separating ownership from control. Based on this well-known conclusion in the literature, and based on the impacts of the separation of ownership from control (voting rights) and the entrenchment of the managers (on the job-consumption) discussed in the paper, hypothesis formulation was drawn and tested.

Managers with relatively small equity ownership may be concerned with considerations other than firm value maximization (reputation, bonuses, job security, etc.). Therefore, they are likely to have the incentives to distort accounting earnings to achieve their objectives. Interestingly, a study by Warfield, Wild and Wild (1995); and Baker, Lopez, Reitenga and Rush (2019) find that the magnitude of earnings management activity, measured by the absolute value of dictionary accruals, is negatively related to managerial ownership. That is, as managerial ownership increases, managerial and shareholder incentives converge leading to a decline in earnings management activities.

The research on earnings management has predominantly addressed the U.S.A, where the dispersed ownership structure leaves the relevant agency problem as that between managers and shareholders. Elsewhere around the world, however, corporate ownership is concentrated (La Porta, Lopez-de-Silanes and ${ }^{4}$ Yet, the results of Healy (1985); Holthausen, Larcker, \& Sloan (1995); Kontesa, Brahmana and Tong (2021) are contradictory when earnings fall below the bonus plan lower bound. Healy (1985) find that managers understate earnings, while Holthausen, Larcker, \& Sloan (1995); and Kama and Melumad (2020) find that managers overstate earnings. 
Shleifer, 1999; Gadhoum, Gueyie and Bergeron, 2007; and Gadhoum, 2015). Unlike atomistic shareholders who face a free-rider problem that limits their incentives to monitor managers, large shareholders have the incentives and ability to do so. If managers engage in opportunistic earnings management and the market subsequently discovers that firm performance was manipulated, then shareholders will revise their expectations about future firm performance and discount the stock price accordingly ${ }^{5}$. When monitoring costs are lower than the effects of the price discount on large shareholder stake, then the large shareholder is better off if he monitors managers to prevent them from manipulating firm performance ${ }^{6}$. Moreover, the illiquid nature of large shareholders stakes provides them with an additional monitoring incentive because it prevents a potential "exit" strategy (Bhide, 1993; Alharbi, Atawnah, Al Mamun and Jahangir, 2020). Large shareholders monitoring incentives vary directly with their cash flow rights. This is because earnings management adverse effects on large shareholders wealth increase with their cash flow rights. Therefore, we conjuncture that the more the large shareholders cash flow rights increase, the more monitoring incentives increase and earnings management decreases. This leads to the first hypothesis:

$H_{1}$ : The magnitude of earnings management activity is negatively related to the cash flow rights of the largest ultimate owner.

Recent research in international corporate governance reveals that large shareholders often achieve control in excess of their cash flow rights (Claessens, Djankov and Lang, 2000; Faccio and Lang, 2002; Gadhoum, 2016). This separation between ownership and control is accomplished through the use of pyramidal structures, multiple classes of shares, and crossholdings. Such mechanisms allow the ultimate owner to effectively control a firm while holding an undersized fraction of cash flow rights. As a result, the ultimate owner's incentives might be distorted toward generating private benefits (i.e., benefits not shared with other shareholders). This is because the ultimate owner internalizes only a fraction (proportional to his cash flow rights) of the value effects of his actions $^{7}$. The separation between ownership and control achieved by large shareholders outside the U.S.A may look like that achieved by U.S professional ${ }^{5}$ Dechow, Sloan and Sweeney (1996) find that firms subject to Securities Exchange Commission investigation for earnings manipulation experience on average a significant $9 \%$ stock price drop upon announcement. Haga, Höglund and Sundvik (2018) arrived to similar findings.

${ }^{6}$ In several cases, large shareholders, especially when they are families, are also the managers. In these cases there is no monitoring (monitoring costs are zero) and large shareholders simply abscond from manipulating firm performance (Cheng, Lee and Shevlin, 2016).

${ }^{7}$ For example, consider a simple three-layer pyramidal structure. An ultimate owner controls $51 \%$ of the equity of firm A, firm A controls $51 \%$ of the equity of firm B, and firm B controls $51 \%$ of the equity of firm C. The ultimate owner has effective control over firm C, however he only holds $51 \%$ $\times 51 \% \times 51 \%=13.27 \%$ of its cash flow rights. Because of the separation between ownership and control in firm C, the ultimate owner internalizes only a fraction $(13.27 \%)$ of the outcome of his actions in firm C. Therefore, the ultimate owner has the incentives and ability to engage in self-dealing at the expense of minority shareholders. For example, the ultimate owner could direct firm A to sell some assets to firm $\mathrm{C}$ at a premium over the market price. In this case, the ultimate owner expropriates $51 \%-13.27 \%(=37.73 \%)$ of the premium from minority shareholders of firm 
managers: in both cases large shareholders and managers are in control, yet they hold lower cash flow rights. However, as noted by Bebchuk et al. (2000), large shareholders as compared to professional managers are virtually insulated from the market for corporate control. Therefore, the separation between ownership and control achieved by large shareholders is likely to create more acute agency problems (Jiang, Ma and Wang, 2020).

A growing body of research reports evidence on the agency costs of separation between ownership and control achieved by controlling shareholders. For example, Bertrand, Mehta and Mullainathan (2002) study inter-corporate transfers between Indian pyramidal affiliated firms. Same was done for Canadian listed firms (Gadhoum, 2016). They find evidence that ultimate owners do tunnel profits from bottom to top (i.e. from low cash flow rights affiliates to high cash flow rights affiliates). Attig, Fischer and Gadhoum (2003) look at the valuation of a sample of 1132 Canadian firms. They find that pyramidal affiliated firms underperform comparable independent firms. Nenova (2003) examines the pricing of multiple voting and restricted shares in a large sample of firms from 18 countries. After controlling for the characteristics of each class of shares such as liquidity and dividends, she finds that multiple voting shares trade at a significant premium. This premium can be interpreted as a lower bound for private benefits of the controlling shareholder. Bae et al. (2002) study rescue mergers in Korean chaebols which are an extensive network of crossholdings ${ }^{8}$. They found that, by forcing financially viable affiliates to overbid for financially distressed affiliates, the ultimate owner transfers wealth from minority shareholders to other chaebol firms.

The evidence shows that the separation between ownership and control enables ultimate owners to extract private benefits. Therefore, ultimate owners may have the incentives to distort accounting numbers in an attempt to camouflage their private benefits and mislead outside shareholders about the true performance of their firms. This is likely because outside shareholders may lack the incentives and resources to monitor the ultimate owner's opportunistic earnings management. This leads to our second hypothesis:

$\mathrm{H}_{2}$ : The magnitude of earnings management activity is higher in firms exhibiting a separation between ownership and control, i.e. firms controlled through the use of pyramidal structures, multiple classes of shares, and crossholding.

However, we do not anticipate that the magnitude of earnings management to be the same in firms exhibiting a separation between ownership and control. We hypothesised that earrings management is a tool for ultimate owners to camouflage their private benefits. Private benefits are not the same in all firms, but they depend on the extent of separation between ownership and control. This is because as the wedge between ownership and control increases, ultimate owners internalize a decreasing fraction of the value effects of their actions. Consistent with this, Claessens, Djankov, Fan and Lang (2002); Lins (2003); and Gadhoum ${ }^{8}$ Rescue mergers are mergers between a financially viable and a financially distressed firm from the same chaebol. 
(2016) find that firm performance is negatively related to the extent of separation between ownership and control. Therefore, we expect that as the separation between ownership and control increases, the level of private benefits extracted by ultimate owner's increases, and the magnitude of earnings management activity necessary to mask private benefits increases. This leads to our third hypothesis:

$H_{3}$ : The magnitude of earnings management activity is positively related to the extent of separation between ownership and control rights achieved by the largest ultimate owner.

\subsection{Second Ultimate Owner}

Since earnings management may be viewed as an agency problem arising from the separation between ownership and control, recent research in the U.S.A has emphasized the role of internal and external governance mechanisms to discipline managers and curb earnings management. Xie, Davidson and DaDalt III (2003); Klein (2002); and Badolato, Dnelson and Ege (2014) find that variables related to the effectiveness of board and audit committee (e.g., size and independence) are negatively correlated with their measures of earnings management. Chung et al. (2002) find that the presence of large institutional investors helps reduce earnings management. While such governance mechanisms may be effective in widely held firms run by professional managers, they are unlikely to be successful in the presence of controlling shareholders. For example, the board and audit committee may not be independent as controlling shareholders are likely to appoint their relatives ${ }^{9}$. Outside the U.S.A where ownership and control are concentrated, some authors point to legal and extra-legal institutions (Haw, $\mathrm{Hu}$, Hwang and $\mathrm{Wu}, 2004$ ) and investor protection (Leuz, Nanda and Wysocki, 2003; Lim, How and Verhoeven, 2014; and Kama and Melumad, 2020) as binding mechanisms for controlling shareholders opportunistic earnings management. In this paper, we look at an alternative governance mechanism, namely the presence of a second ultimate owner. The governance role of multiple large shareholders is highlighted in some theoretical models. For instance, Gomes and Novaes (1999) as well as Alharbi, Atawnah, Al Mamun and Jahangir (2020) argue that the presence of multiple large shareholders creates bargaining problems that may prevent decisions that harm outside shareholders. Moreover, they suggest that, in equilibrium, the presence of multiple large shareholders should be pervasive in firms where the incentives for diluting minority shareholders are high. Bennedsen and Wolfenzon (2000) and Jiang, Ma and Wang (2020) argue that any decision that potentially hurts minority shareholders needs the consent of a coalition of large shareholders. A coalition, however, will have more cash flow rights and less separation between ownership and control than a single ${ }^{9}$ Park and Shin (2004) as well as Cheng, Lee, \& Shevlin (2016) examine the role of the board of directors as an internal governance device to limit earnings management in Canada from 1991 to 1997. The authors find little evidence on the effectiveness of boards. For example, they report neither that independent members nor their average tenure decrease earnings management. 
controlling shareholder. Therefore, a coalition is less likely to engage in opportunistic dealing at the expense of minority shareholders, since it internalises more of the consequences of its actions. For the reasons presented above, we therefore expect that the presence and the bargaining power of a second ultimate owner inhibit the largest ultimate owner incentives to manage earnings. This leads to our fifth hypothesis:

$H_{4}$ : The magnitude of earnings management activity is negatively related to the presence of a second ultimate owner and to his bargaining power vis-à-vis the largest ultimate owner.

\subsection{Family Firms}

Thus far, we have discussed the potential effects of ownership concentration, the separation between ownership and control achieved by large shareholders, and the role of a second large shareholder on earnings management activity. Another issue that might affect earnings management activity is the identity of large shareholders. We focus on a popular type of large shareholders, namely families, because the governance of family firms is presumably different from that of other firms. First, corporate governance in family firms may differ because families as controlling shareholders are thought to derive a special type of private benefits, namely amenities (Demsetz and Lehn, 1985). Amenities refer to the utility derived from shaping the firm's decision making. That is families may allocate resources so as to suit their personal preferences and not in a perspective of value maximization. Demsetz and Lehn (1985) point to the sports and mass media industries as industries conferring large amenities potential ${ }^{10}$. Consistent with families consuming amenities, Slovin and Sushka (1993) report that announcements of the death of founders generate a significant positive stock price reaction. Moreover, Morck, Strangeland and Yeung (2000); Attig, Fischer and Gadhoum (2003); Gadhoum (2015) find that Canadian family firms under perform their Canadian and U.S peers, respectively. Second, it has been suggested that families are well positioned to engage in political rent-seeking. Morck et al. (2000) advocate that families long tenure in management makes them a preferred partner for corrupt politicians since they are more likely to return past favors ${ }^{11}$. Faccio (2004) study the extent of political connections in a large sample of firms from 47 countries. She finds that political connections are pervasive around the world and that politically connected firms underperform non-connected firms. Her results suggest that the costs of political connections (e.g., bribes) are larger than the potential benefits (government favors). Third, families are suggested to build and preserve "family names" and reputation. Reputation may constitute first-rate collateral when transacting in less than perfect markets. For ${ }^{10}$ See Demsetz and Lehn (1985: footnote 4, page 1162) for several examples of amenities consumption in family controlled firms.

${ }^{11}$ For instance, one of K. C. Irving's (the founder of the Irving group) sons said "My father never lost a New Brunswick election in his life" even though Irving never sought public office (see Francis, 1986: p. 10). 
example, Khanna and Rivkin (2001) highlight the role of family reputation in product markets as a commitment to produce high-quality goods. Likewise, Anderson, Mansi and Reeb (2003) argue and find that debt financing is cheaper for family firms presumably because of family's reputation.

What are the consequences of the (different) governance of family firms on earnings management activity? If families extract extra private benefits in the form of amenities and political connections, then one might expect families to engage in more earnings management in order to disguise these private benefits. This is particularly the case for political connections as the firm and its corrupt politician's partners may require secrecy and, hence, accounting numbers may be manipulated to preserve secrecy. Moreover, if family's reputation is related to firm performance, then families may have the incentives to manage earnings to preserve their reputation. Beyond their incentives to manage earnings, families are likely to have the facility. Attig et al. (2006) show that bid-ask spreads are higher in family firms, suggesting that family firms operate in a more opaque environment. Therefore, minority shareholders of family firms may not be able to detect earnings management. This leads to our final hypothesis ${ }^{12}$ :

$H_{5}$ : The magnitude of earnings management activity is higher in family controlled firms.

\section{Data}

In this section, we describe the data sources, the construction of the ownership structure variables, the earnings management measure, and the control variables.

\subsection{Measuring Earnings Management}

Along the lines of previous research, we rely on total accruals to derive our measure of earnings management. Total accruals are defined as the change in noncash current assets minus the change in current operating liabilities minus depreciation and amortization expenses. Thus:

$$
T A C_{j, I, t}=\left(\Delta C A_{j, I, t}-\Delta \operatorname{Cash}_{j, I, t}\right)-\left(\Delta C L_{j, I, t}-\Delta S T D_{j, I, t}\right)-\operatorname{Dep}_{j, I, t},
$$

where, for firm $j$, in industry $I$, at time $t, T A C_{j, I, t}=$ total accruals; $\Delta C A_{j, I, t}=$ change in current assets; $\Delta \operatorname{Cash}_{j, I, t}=$ change in cash and cash equivalents; $\Delta C L_{j, I, t}=$ change in current liabilities; $\Delta S T D_{j, I, t}=$ change in current portion of long-term debt; $D e p_{j, I, t}=$ depreciation and amortization expenses.

We follow standard methodology and decompose total accruals into a discre-

\footnotetext{
${ }^{12}$ Managerial job security is one motivation for earnings management in widely held firms (Fudenberg and Tirole, 1995; Dou, Khan and Zou, 2016). Therefore, one may argue that since families have longer horizons than professional managers, they have fewer incentives to manage earnings. However, the horizon argument is unlikely, at least in the Canadian context. For instance, Morck, Strangeland and Yeung (2000) report that research and development expenditures, which are long-term investments, are lower in family controlled firms. Note that the horizon problem would imply the contrary, since families (professional managers) with long (short) horizon would over (under) invest in research and development expenditures that generate returns after a long period of time.
} 
tionary and a non-discretionary component. Discretionary accruals are under managerial control, while non-discretionary accruals depend on the economic activity of the firm. To disentangle these two components, we use a modified version of the traditional model. It is suggested that non-discretionary accruals are related to (1) changes in sales and (2) the level of gross property, plant, and equipment. Changes in sales control for non-discretionary changes in working capital accounts, while the level of gross property, plant, and equipment controls for non-discretionary depreciation expenses. The model is as follows:

$$
\frac{T A C_{j, I, t}}{A_{j, I, t-1}}=\alpha_{I, t} \frac{1}{A_{j, I, t-1}}+\beta_{I, t} \frac{\Delta \text { Sales }_{j, I, t}}{A_{j, I, t-1}}+\gamma_{I, t} \frac{P P E_{j, I, t}}{A_{j, I, t-1}}+\varepsilon_{j, I, t},
$$

where, for firm $j$, in industry $I$, at time $t, A_{j, I, t-1}=$ total assets; $\Delta$ Sales $_{j, I, t}=$ change in sales; $P P E_{j, I, t}=$ Property, plant, and equipment; $\varepsilon_{j, I, t}=$ error term.

All variables are scaled by beginning-of-period total assets to control for heteroscedasticity in the data. The regression is estimated by ordinary least squares using all firms in industry $I$, at time $t$ in the StockGuide database (Gadhoum, 2015). Industry-years with less than 6 observations are excluded from the regression. The predicted values of the dependent variable in regression (2) are the proxy non-discretionary accruals. However, as suggested by Dechow, Sloan and Sweeney (1996), we adjust non-discretionary accruals for the change in accounts receivables. We do so because this modified version of the Jones (2018) model has been shown to exhibit the most power amongst several models in detecting earnings management. Thus, non-discretionary accruals $\left(N D A C_{j, I, t}\right)$ are defined as follows:

$$
N D A C_{j, I, t}=\hat{\alpha}_{I, t} \frac{1}{A_{j, I, t-1}}+\hat{\beta}_{I, t} \frac{\Delta \text { Sales }_{j, I, t}-\Delta A R_{j, I, t}}{A_{j, I, t-1}}+\hat{\gamma}_{I, t} \frac{P P E_{j, I, t}}{A_{j, I, t-1}},
$$

where, for industry $I$, at time $t, \hat{\alpha}_{I, t}, \hat{\beta}_{I, t}, \hat{\gamma}_{I, t}=$ parameter estimates from regression (2), $\Delta A R_{j, I, t}=$ change in accounts receivables.

Finally, discretionary accruals, our proxy of earnings management are the predicted residuals from regression (2). Thus, discretionary accruals $\left(D A C_{j, I, t}\right)$ are defined as follows:

$$
D A C_{j, I, t}=\frac{T A C_{j, I, t}}{A_{j, I, t-1}}-N D A C_{j, I, t} .
$$

We apply the preceding procedure to all firms, excluding firms from the financial services industry and firms classified as conglomerates, with available date over the three year period 1995-1997.

\subsection{Data for Ultimate Ownership}

We collect ownership data for a sample of Canadian firms listed in the 1996 version of the StockGuide database. Data on the identity and size of shareholder holdings is collected manually from two principal sources: 1) The Financial Post 
(FP) "Survey of Industrials" and "Survey of Mines and Energy Resources", and 2) Statistics Canada Intercorporate Ownership in Canada. We follow the methodology adopted in La Porta et al. (1999); Claessens et al. (2000); and Gadhoum (2015) to construct our ownership structure variables. Firms are classified as widely held or having a controlling shareholder. A firm is classified as having a controlling shareholder if this shareholder controls at least $20 \%$ of the outstanding votes. In many cases, the controlling shareholders are corporate entities or financial institutions. In those cases, we identify their owners, the owners of their owners, and so on. This procedure is stopped when we encounter one of the following ultimate owners: 1) an individual or a family, 2) the government, 3) a widely held corporation, 4) a widely held financial institution, 5) miscellaneous (trusts, charities, non-profit organizations, etc.) ${ }^{13}$.

Our definitions of ownership and control rely on cash flow and voting rights. These two measures may differ because of the use of multiple classes of shares, pyramidal structures, cross-holdings, and reciprocal holdings.

When a corporation issues several types of shares conferring different voting rights then we are in presence of multiple classes of shares. For instance suppose that a given firm issues 100 class A shares giving 10 votes per share and 1000 class B shares giving 1 vote per share. The two classes of shares are entitled to the same dividend rate. Suppose that a shareholder owns 100 class A shares and 100 class $B$ shares. Therefore, this shareholder owns $(100+100) /(100+1000)=$ $18.2 \%$ of ownership rights and $(100 \times 10+100 \times 1) /(100 \times 10+1000 \times 1)=55 \%$ of voting rights.

A corporation belongs to a pyramidal structure if it has an ultimate owner who controls it through (at least one) another corporation. For example, suppose that a family owns $25 \%$ of Firm Y (with all shares giving 1 vote), which in turn owns $20 \%$ of Firm $\mathrm{Z}$ (with all shares giving 1 vote), then we would say that the family owns $20 \% \times 25 \%=5 \%$ of the cash-flow rights of Firm Y-the product of the ownership stakes along the chain-and controls $\operatorname{Min}(20 \%, 25 \%)=20 \%$ of Firm $\mathrm{Y}$-the smallest percentage in the chain of voting rights.

A corporation is controlled through cross-holdings if it has an ultimate owner who controls it through multiple control chains. Suppose that a family owns $20 \%$ of Firm Y and $30 \%$ of Firm Z. Firm Y in turn owns $10 \%$ of firm Z. In this case firm $\mathrm{Z}$ is controlled through cross-holding. The family owns $(20 \%+30 \% \times$ $10 \%)=23 \%$ of firm $Z^{\prime}$ cash flow rights and $[30 \%+\operatorname{Min}(20 \%, 10 \%)]=40 \%$ of firm Z' control rights.

For each firm in the sample, we determine the ownership and control rights of the largest and the second ultimate owner, if any. We employ three variables to document the separation between ownership and control achieved by the largest ultimate owner: 1) the difference between control rights and cash flow right, 2) a ${ }^{13}$ In some circumstances we are not able to trace back the ultimate owners and their ultimate ownership and control stakes. This is particularly the case of affiliates of foreign firms and firms for which a significant fraction of shares is held in nominee accounts. These firms are then excluded from the sample. 
dummy variable that takes the value of one if control rights are larger than cash flow rights, and zero elsewhere, and 3) a dummy variable that takes the value of one if the gap between control and ownership is higher than the median gap. We also identify the means used by the ultimate owners to enhance their control and accentuate the separation of control from ownership. For that purpose, we use a set of dummy variables to verify the presence pyramidal holding, multiple classes of shares, and crossholding. Finally, to examine whether or not the second ultimate owner impedes earnings management, we employ to variables. The first is a dummy variable that take one if there is two ultimate owners, and zero otherwise. The second is a proxy for the second ultimate owner bargaining power and is equal to the ratio of the second ultimate owner voting rights to the largest ultimate owner voting rights.

\subsection{Control Variables}

In addition to ownership structure variables, we employ a set of control variables commonly used as determinants of earnings management. Our control variables include the market-to-book ratio, the long-term leverage ratio, the natural logarithm of total assets, the absolute difference in ROA from year $t-1$ to year $t$, a negative net income dummy, and the absolute value of year $t-1$ ROA.

Growth firms may invest in working capital to support future sales growth (Kothari, Leone and Wasley, 2005; and Baker, Lopez, Reitenga and Ruch, 2019). Also growth firms are thought to exhibit more asymmetric information than mature firms suggesting that they have more discretion to manage earnings without attracting external scrutiny. Hence, we expect a positive relation between firm's growth opportunities and earnings management activity. We measure growth opportunities by the market-to-book ratio of assets defined as the ratio of total assets minus book equity plus market capitalization over total assets.

Large firms are more likely to attract external monitoring (e.g., financial analysts, media, etc.) than smaller firms. Therefore, large firms are less likely than smaller firms to engage in earnings management because of the greater likelihood of being caught for earnings manipulation. We use the natural logarithm of total assets as a proxy for firm size and expect it to have a negative relation with earnings management activity.

Financially distressed firms may deliberately manipulate earnings to avoid violating debt covenants or to delay technical default (Du and Shen, 2018). For instance DeFond and Jiambalvo (1994) report those firms engaged in income increasing accounting manipulation prior to debt covenant violation. Hence we control for the financial health of the firm using the long-term leverage ratio (i.e., the ratio of long term debt to total assets). We expect the long-term leverage ratio to be positively related to earnings management.

Klein (2002) and Alharbi, Mamun, \& Atawnah (2021) highlight the importance of controlling for the firm's earnings process as a determinant of discretionary accruals. The author argues that prior years accruals reversals may result 
in measurement errors, which in turn may produce incorrect inferences. Following Klein (2002), we employ two proxies for the earnings process: 1) the absolute difference in ROA from year $t-1$ to year $t$, and 2) a dummy variable that equals one if the firm exhibited a negative net income during the last three years, and zero otherwise.

Previous research reports that discretionary accruals models may not behave well if the firm exhibited past extreme performance (Dechow, Sloan and Sweeney, 1996; Rangan, 1998). Therefore, we control for past extreme performance using the absolute value of $R O A$.

\section{Descriptive Statistics}

Table 1 shows the industry distribution of sample firms (columns 2 and 3) and the entire population of firms in StockGuide (columns 4 and 5) as a benchmark. Firms from the pipelines, tobacco, department stores, machinery and structural steel, steel distributing and servicing industries were excluded because we required at least six observations per industry to calculate discretionary accruals. They were excluded because they didn't match the sampling criteria used in this paper. A manual scrutiny of each observation in each industry for the whole sample was performed using this criterion. The reason for choosing at least six observations per industry is to allow for discretionary accruals to remain in the sub sample for the afterwards computation and to assure the robustness and the asymptotic accuracy of the computation of the accruals which is already problematic and subject to controversy among scholars in the field (Kama and Melumad, 2020). Firms from the financial services industry and firms classified as conglomerates were also excluded because it is hard in these two cases to get a quite valid way to get a proxy of the earnings management given the nature of their pyramidal ownership structure and their cross-ownership. The sample is dominated by firms from the natural resources sector followed by firms from the technological sector which account in aggregate for $35.66 \%$ and $16.24 \%$ of sample firms, respectively. These descriptive results as many others are not reported

Table 1. Industry distribution of sample firms in 1996.

\begin{tabular}{lccccc}
\hline \multicolumn{1}{c}{ Industry } & \multicolumn{2}{c}{ Sample } & \multicolumn{2}{c}{ StockGuide } \\
\hline Integrated mines & $\mathrm{N}$ & percentage & $\mathrm{N}$ & percentage \\
Mining & \multicolumn{2}{c}{ Excluded } & 7 & 0.68 \\
Gold and precious minerals & 22 & 2.79 & 30 & 2.94 \\
Mining exploration-no production & 75 & 9.52 & 91 & 8.90 \\
Integrated oils & 21 & 2.66 & 26 & 2.54 \\
Oil \& gas producers & 4 & 0.51 & 6 & 0.59 \\
Oil \& gas, mining, or forest services & 114 & 14.47 & 156 & 15.26 \\
Pipelines & 23 & 2.92 & 30 & 2.94 \\
\hline
\end{tabular}




\section{Continued}

\begin{tabular}{|c|c|c|c|c|}
\hline Paper \& forest products & 26 & 3.30 & 31 & 3.03 \\
\hline Building materials & 10 & 1.27 & 17 & 1.66 \\
\hline Autos and parts & 13 & 1.65 & 21 & 2.05 \\
\hline Breweries \& beverages & 7 & 0.89 & 9 & 0.88 \\
\hline Distilleries & 3 & 0.38 & 6 & 0.59 \\
\hline Food processing & 19 & 2.41 & 24 & 2.35 \\
\hline Household goods & 37 & 4.70 & 40 & 3.91 \\
\hline Tobacco & \multicolumn{2}{|c|}{ Excluded } & 2 & 0.20 \\
\hline Department stores & \multicolumn{2}{|c|}{ Excluded } & 2 & 0.20 \\
\hline Food stores & 4 & 0.51 & 6 & 0.59 \\
\hline Biotechnology/pharmaceuticals & 41 & 5.20 & 50 & 4.89 \\
\hline Hospitality & 11 & 1.40 & 12 & 1.17 \\
\hline Restaurants & 5 & 0.63 & 9 & 0.88 \\
\hline Specialty stores & 26 & 3.30 & 33 & 3.23 \\
\hline Wholesale distributors \& importers & 13 & 1.65 & 16 & 1.57 \\
\hline Business services & 18 & 2.28 & 20 & 1.96 \\
\hline Chemicals and fertilizers & 16 & 2.03 & 20 & 1.96 \\
\hline Electrical \& electronic products & 7 & 0.89 & 7 & 0.68 \\
\hline Machinery \& structural steel & \multicolumn{2}{|c|}{ Excluded } & 4 & 0.39 \\
\hline Fabricating \& engineering & 21 & 2.66 & 28 & 2.74 \\
\hline Specialty industries & 27 & 3.43 & 31 & 3.03 \\
\hline Steel producers & 10 & 1.27 & 10 & 0.98 \\
\hline Steel distributing \& servicing & \multicolumn{2}{|c|}{ Excluded } & 4 & 0.39 \\
\hline Transportation equipment & 6 & 0.76 & 7 & 0.68 \\
\hline Industrial contractors & 6 & 0.76 & 6 & 0.59 \\
\hline Technology-hardware & 52 & 6.60 & 63 & 6.16 \\
\hline Technology—software & 35 & 4.44 & 44 & 4.31 \\
\hline Transportation \& environnemental services & 21 & 2.66 & 27 & 2.64 \\
\hline Gas \& electrical utilities & 12 & 1.52 & 14 & 1.37 \\
\hline Telephone utilities & 11 & 1.40 & 18 & 1.76 \\
\hline Broadcasting & 7 & 0.89 & 9 & 0.88 \\
\hline Cable \& entertainment & 28 & 3.55 & 31 & 3.03 \\
\hline Publishing \& printing & 9 & 1.14 & 11 & 1.08 \\
\hline Real estate \& construction & 28 & 3.55 & 41 & 4.01 \\
\hline Financial services & \multicolumn{2}{|c|}{ Excluded } & \multicolumn{2}{|c|}{ Excluded } \\
\hline Conglomerates & \multicolumn{2}{|c|}{ Excluded } & \multicolumn{2}{|c|}{ Excluded } \\
\hline Total & 788 & 100 & 1022 & 100 \\
\hline
\end{tabular}


here because they have no valuable additional information to the aim of the paper which is not the characterization of Canadian ownership structure or the industry effect on ownership (Demsetz and Lehn, 1985). On the other hand, after elimination of observations which do not allow computing the accruals, we remain with a sub-sample and the characterization could be different. The explanation of this change is not part of the motivation of the paper tackling the ownership structure of a firm effect/role on the earnings management.

Summary statistics on ownership structure variables are shown in Table 2. Panel A illustrates the ownership and control distribution of the largest ultimate owner. The mean (median) cash flow rights is $21.19 \%$ (16.9\%) while the mean (median) voting rights is $27.94 \%$ (23.77\%). These figures suggest that not only Canadian corporate ownership is concentrated but also that ultimate owners are able to achieve a separation between ownership and control. Panel B reports the means employed by the largest ultimate owner to achieve such a separation between ownership and control. Near 30\% of sample firms are controlled through pyramidal holdings, $15.65 \%$ through multiple classes of shares and $7.54 \%$ through cross-holding. Panel C reports the identity of ultimate owners. It shows that $56.82 \%$ of sample firms do have an ultimate owner. Of the firms having an ultimate owner, $56.58 \%$ are controlled by a family, $8.64 \%$ by a widely held firm,

Table 2. Ownership structure variables. (a) Panel A. Ultimate ownership and control rights of the largest ultimate owner $(\mathrm{N}=788)$; (b) Panel B. Means of separating ownership from control ( $\mathrm{N}=788)$; (c) Panel C. Ultimate owner identity $(\mathrm{N}=788)$; (d) Panel D. Ultimate ownership and control rights of the second largest ultimate owner $(\mathrm{N}=142)$.

(a)

\begin{tabular}{lccccc}
\hline & Mean & Std. dev & Q1 & Median & Q3 \\
\hline Cash flow rights & 21.19 & 20.07 & 0 & 16.90 & 31.84 \\
Control rights & 27.94 & 23.18 & 0 & 23.77 & 44.16 \\
Control rights minus cash flow rights & 6.75 & 14.53 & 0 & 0 & 3.80 \\
\hline
\end{tabular}

(b)

\begin{tabular}{ccc}
\hline Pyramidal structure & Multiple classes of shares & Cross-holding \\
\hline $29.88 \%$ & $15.65 \%$ & $7.54 \%$ \\
\hline
\end{tabular}

(c)

\begin{tabular}{cccccc}
\hline $\begin{array}{c}\text { Firms having an } \\
\text { ultimate owner }\end{array}$ & \multicolumn{2}{c}{$\begin{array}{c}\text { Widely } \\
\text { held firm }\end{array}$} & $\begin{array}{c}\text { Widely held } \\
\text { financial institution }\end{array}$ & Government Miscellaneous \\
\hline $56.82 \%$ & $56.58 \%$ & $8.64 \%$ & $19.43 \%$ & $5.15 \%$ & $10.20 \%$ \\
\hline
\end{tabular}

(d)

\begin{tabular}{cccccc}
\hline & Mean & Std. dev & Q1 & Median & Q3 \\
\hline Cash flow rights & 19.06 & 11.93 & 8.51 & 21.50 & 26.00 \\
Control rights & 27.97 & 7.95 & 22.30 & 25.40 & 33.00 \\
Bargaining power & 0.78 & 0.22 & 0.61 & 0.84 & 0.98 \\
\hline
\end{tabular}


$19.43 \%$ by a widely held financial institution, $5.15 \%$ by the government, and $10.20 \%$ by miscellaneous investors. Finally, panel D illustrates the ownership and control distribution along with the bargaining power of the second ultimate owner. Second ultimate owners are present in 142 firms accounting for $18.02 \%$ of the sample. The mean (median) cash flow rights of the second ultimate owner is $19.06 \%(21.50 \%)$ while the mean (median) voting rights is $27.97 \%(25.40 \%)$. The mean (median bargaining power of the second ultimate owner is $0.78(0.98)$.

Panel A of Table 3 provides summary statistics for total, non-discretionary and discretionary accruals. The mean (median) total accruals scaled by lagged total assets are $-0.0502(-0.0402)$. The mean (median) discretionary accruals is $-0.0409(-0.0335)$, suggesting that over the sample period the average firm engaged in income decreasing earnings management. Panel B provides summary statistics for the set of control variables.

\section{Regression Analysis}

In this section we present the results of a regression analysis intended to test our hypotheses about the relationship between earnings management activity and corporate governance. Following previous research (e.g., Warfield, Wild and Wild, 1995; Klein, 2002), we use the natural logarithm of unsigned discretionary accruals as the dependent variable. Ultimate ownership and control variables are used as explanatory variables along with year and industry dummies to control for year and industry fixed effects on earnings management. However, for simplicity we do not report their coefficients. The statistical significance of the regression coefficients is based on the Newey and West (1987) covariance matrix to avoid problems associated with possible autocorrelation and heteroscedasticity of the residuals.

Table 4 presents regression results that associate unsigned discretionary accruals

Table 3. Descriptive statistics for accruals and estimated non-discretionary and discretionary accruals.

\begin{tabular}{lccccc}
\hline & Mean & $\begin{array}{c}\text { Standard } \\
\text { deviation }\end{array}$ & Q1 & Median & Q3 \\
\hline Panel A. & & & & & \\
\hline Total accruals (TAC/TA) & -0.0502 & 0.4116 & -0.1015 & -0.0402 & 0.0052 \\
Non-discretionary accruals (NDAC) & -0.0092 & 0.3532 & -0.0372 & -0.0044 & 0.0193 \\
Discretionary accruals (DAC) & -0.0409 & 0.2816 & -0.0918 & -0.0335 & 0.0128 \\
\hline Panel B. & & & & & \\
\hline Market-to-book ratio & 2.07 & 5.24 & 1.04 & 1.35 & 2.01 \\
Long-term leverage ratio & 0.1783 & 0.2179 & 0.0040 & 0.1283 & 0.2797 \\
Total assets (in million \$) & 563.683 & 2145.296 & 23.708 & 65.842 & 298.525 \\
Abs. difference in ROA & 0.2060 & 3.8798 & 0.0129 & 0.0364 & 0.1001 \\
Return on assets (ROA) & -0.0678 & 1.2555 & -0.0418 & 0.0231 & 0.0630 \\
\hline
\end{tabular}


to the ownership and means of enhancing control of the largest ultimate owner. The table presents five models. Model 1 provides a formal test of the first hypothesis $\left(H_{1}\right)$. The natural logarithm of unsigned discretionary accruals is regressed on the ownership rights of the largest ultimate owner and control variables. The coefficient of the cash flow rights variable is negative and highly significant ( $p$-value $<0.0001)$. The results also suggest that ownership concentration is economically significant. Ceteris paribus, a one percent increase in the ownership rights of the largest ultimate owner decreases unsigned discretionary accruals by almost $8 \%$. The aim of models $2,3,4$ and 5 is to test our second hypothesis $\left(H_{2}\right)$. In model 2, 3 and 4 , the natural logarithm of unsigned discretionary accruals is regressed on the pyramidal holding dummy, the multiple classes of shares dummy and crossholding dummy separately while in model 5 all the variables are included in the regression. In all models, the ownership rights variable is included to account for the coexistence of two opposing incentives 1) to decrease earnings management arising from ownership concentration and 2) to increase earnings management arising from the separation between ownership and control. In all models, the ownership rights coefficient has a similar sign, magnitude and statistical significance as in model 1 . When estimated separately (models 2, 3 and 4), all three dummy variables have positive coefficients, yet only the pyramidal holding and multiple classes of shares coefficients are statistically significant (at the $1 \%$ level). From an economic point of view, our results suggest that unsigned discretionary accruals are $24 \%$ and $34 \%$ higher in firms controlled through pyramidal holdings and multiple classes of shares, respectively. When estimated jointly (model 5), the pyramidal holding and the multiple classes of shares coefficients have consistently the same sign, magnitude and statistical significance. The crossholding dummy coefficient sign changes and become negative, yet it is not statistically significant.

Overall, the evidence in Table 4 is consistent with our first two hypotheses. Earnings management is significantly negatively related to the ownership rights of the largest ultimate owner and significantly higher in firms where he largest ultimate owner achieves a separation between ownership and control (except firms controlled through crossholdings).

The coefficient of the market-to-book ratio is positive and statistically significant in all models, consistent with the arguments that growth firms over invest in working capital to sustain future sales growth and that they have more discretion to manage earnings because of asymmetric information. The coefficient of the long-term leverage ratio is positive in all models but statistically significant only in models 1, 2 and 4. As such, there is mixed evidence that highly leveraged firms carry out more earnings management to avoid violating debt covenants or to delay technical default. The coefficient of the logarithm of total assets is negative and statistically significant, consistent with the argument that large firms attract more external monitoring. The coefficient of the absolute value of the difference in $R O A$ is positive and significant suggesting that earning process have 
Table 4. The effects of means of enhancing control on abnormal accruals.

\begin{tabular}{|c|c|c|c|c|c|}
\hline Independent variables & Model 1 & Model 2 & Model 3 & Model 4 & Model 5 \\
\hline Cash flow rights & $\begin{array}{l}-0.0825^{\mathrm{a}} \\
(<0.0001)\end{array}$ & $\begin{array}{l}-0.0859^{\mathrm{a}} \\
(<0.0001)\end{array}$ & $\begin{array}{l}-0.0755^{\mathrm{a}} \\
(<0.0001)\end{array}$ & $\begin{array}{l}-0.0839^{\mathrm{a}} \\
(<0.0001)\end{array}$ & $\begin{array}{l}-0.0800^{\mathrm{a}} \\
(<0.0001)\end{array}$ \\
\hline Pyramidal holding dummy & & $\begin{array}{c}0.2164^{\mathrm{a}} \\
(0.0014)\end{array}$ & & & $\begin{array}{c}0.2232^{\mathrm{a}} \\
(0.0036)\end{array}$ \\
\hline Multiple classes of shares dummy & & & $\begin{array}{c}0.2981^{\mathrm{a}} \\
(0.0017)\end{array}$ & & $\begin{array}{c}0.2897^{\mathrm{a}} \\
(0.0023)\end{array}$ \\
\hline Crossholding dummy & & & & $\begin{array}{c}0.1315 \\
(0.1524)\end{array}$ & $\begin{array}{l}-0.0075 \\
(0.9437)\end{array}$ \\
\hline Market-to-book ratio & $\begin{array}{c}0.0104^{c} \\
(0.0762)\end{array}$ & $\begin{array}{c}0.0134^{c} \\
(0.0921)\end{array}$ & $\begin{array}{l}0.0076^{c} \\
(0.0826)\end{array}$ & $\begin{array}{c}0.0189^{c} \\
(0.0796)\end{array}$ & $\begin{array}{c}0.0164^{c} \\
(0.0962)\end{array}$ \\
\hline Long-term leverage ratio & $\begin{array}{c}0.1605^{c} \\
(0.0758)\end{array}$ & $\begin{array}{c}0.1503^{c} \\
(0.0976)\end{array}$ & $\begin{array}{c}0.1387 \\
(0.1265)\end{array}$ & $\begin{array}{c}0.1534^{c} \\
(0.0905)\end{array}$ & $\begin{array}{c}0.1309 \\
(0.1510)\end{array}$ \\
\hline Log of total assets & $\begin{array}{c}-0.2103^{\mathrm{a}} \\
(0.0001)\end{array}$ & $\begin{array}{c}-0.2138^{\mathrm{a}} \\
(0.0001)\end{array}$ & $\begin{array}{c}-0.21609^{\mathrm{a}} \\
(0.0001)\end{array}$ & $\begin{array}{c}-0.21151^{\mathrm{a}} \\
(0.0001)\end{array}$ & $\begin{array}{c}-0.21928^{\mathrm{a}} \\
(0.0001)\end{array}$ \\
\hline Absolute difference in ROA & $\begin{array}{c}0.1176^{\mathrm{a}} \\
(0.0001)\end{array}$ & $\begin{array}{c}0.1196^{\mathrm{a}} \\
(0.0001)\end{array}$ & $\begin{array}{c}0.1214^{\mathrm{a}} \\
(0.0001)\end{array}$ & $\begin{array}{c}0.1170^{\mathrm{a}} \\
(0.0001)\end{array}$ & $\begin{array}{c}0.1229^{a} \\
(0.0001)\end{array}$ \\
\hline Negative net income dummy & $\begin{array}{c}0.0223 \\
(0.4395)\end{array}$ & $\begin{array}{c}0.0253 \\
(0.3819)\end{array}$ & $\begin{array}{c}0.0240 \\
(0.4059)\end{array}$ & $\begin{array}{c}0.0234 \\
(0.4172)\end{array}$ & $\begin{array}{c}0.0276 \\
(0.3394)\end{array}$ \\
\hline Absolute value of ROA & $\begin{array}{c}0.0158^{c} \\
(0.0891)\end{array}$ & $\begin{array}{c}0.0146^{c} \\
(0.0549)\end{array}$ & $\begin{array}{c}0.0191^{c} \\
(0.0618)\end{array}$ & $\begin{array}{c}0.0255^{c} \\
(0.0682)\end{array}$ & $\begin{array}{c}0.0173^{c} \\
(0.0764)\end{array}$ \\
\hline Intercept & $\begin{array}{l}-0.6046^{c} \\
(0.0610)\end{array}$ & $\begin{array}{c}-0.7080^{\mathrm{b}} \\
(0.0280)\end{array}$ & $\begin{array}{l}-0.5218 \\
(0.1077)\end{array}$ & $\begin{array}{c}-0.6314^{\mathrm{b}} \\
(0.0499)\end{array}$ & $\begin{array}{l}-0.6100^{c} \\
(0.0588)\end{array}$ \\
\hline Adjusted $\mathrm{R}^{2}$ & 0.4710 & 0.4697 & 0.4675 & 0.4709 & 0.4650 \\
\hline Number of observations & 2148 & 2148 & 2148 & 2148 & 2148 \\
\hline
\end{tabular}

${ }^{a}$ statistical significance at the $1 \%$ level. ${ }^{b}$ statistical significance at the $5 \%$ level. ${ }^{c}$ statistical significance at the $10 \%$ level.

an influence on discretionary accruals. The coefficient of the negative net income dummy is not significant, however, suggesting that firms that experienced at last one accounting loss during the last three years do not increase earnings management. The coefficient of the absolute value of $R O A$ is positive and significant, consistent with the argument that extreme performance impact discretionary accruals.

Table 5 contains the results of three regressions intended to test our third hypothesis $\left(\mathrm{H}_{3}\right)$. Again, the dependent variable is the logarithm of unsigned discretionary accruals. In all models, we include the cash flow rights variable to account for the opposing incentives of the largest ultimate owner to manage earnings. In model 1, the variable of interest is the control minus cash flow rights of the largest ultimate owner which have a positive and statistically significant coefficient ( $p$-value $=0.0510)$. This coefficient is also economically significant. A one 
Table 5. The effect of ultimate ownership and control on abnormal accruals.

\begin{tabular}{|c|c|c|c|}
\hline Independent variables & Model 1 & Model 2 & Model 3 \\
\hline Cash flow rights & $\begin{array}{c}-0.0739^{\mathrm{a}} \\
(0.0001)\end{array}$ & $\begin{array}{c}-0.0780^{\mathrm{a}} \\
(0.0001)\end{array}$ & $\begin{array}{c}-0.0740^{\mathrm{a}} \\
(0.0001)\end{array}$ \\
\hline Control minus cash flow rights & $\begin{array}{c}0.0422^{c} \\
(0.0510)\end{array}$ & & \\
\hline Control exceeds cash flow rights dummy & & $\begin{array}{c}0.1763^{\mathrm{b}} \\
(0.0233)\end{array}$ & $\begin{array}{c}0.0729 \\
(0.4596)\end{array}$ \\
\hline Control exceeds cash flow rights, high & & & $\begin{array}{c}0.2226^{c} \\
(0.0896)\end{array}$ \\
\hline Market-to-book ratio & $\begin{array}{l}0.0184^{c} \\
(0.0807)\end{array}$ & $\begin{array}{c}0.0143^{c} \\
(0.0901)\end{array}$ & $\begin{array}{c}0.0107^{c} \\
(0.0758)\end{array}$ \\
\hline Long-term leverage ratio & $\begin{array}{c}0.1396^{\mathrm{b}} \\
(0.0127)\end{array}$ & $\begin{array}{c}0.1461^{\mathrm{b}} \\
(0.0110)\end{array}$ & $\begin{array}{c}0.1354^{\mathrm{b}} \\
(0.0137)\end{array}$ \\
\hline Log of total assets & $\begin{array}{c}-0.2147^{\mathrm{a}} \\
(0.0001)\end{array}$ & $\begin{array}{c}-0.2135^{\mathrm{a}} \\
(0.0001)\end{array}$ & $\begin{array}{l}-0.2149^{\mathrm{a}} \\
(0.0001)\end{array}$ \\
\hline Absolute difference ROA & $\begin{array}{c}0.1207^{\mathrm{a}} \\
(0.0001)\end{array}$ & $\begin{array}{l}0.1215^{\mathrm{a}} \\
(0.0001)\end{array}$ & $\begin{array}{c}0.1214^{\mathrm{a}} \\
(0.0001)\end{array}$ \\
\hline Negative net income dummy & $\begin{array}{c}0.0239 \\
(0.4076)\end{array}$ & $\begin{array}{c}0.0233 \\
(0.4200)\end{array}$ & $\begin{array}{c}0.0263 \\
(0.3630)\end{array}$ \\
\hline Absolute value of ROA & $\begin{array}{c}0.0143^{c} \\
(0.0743)\end{array}$ & $\begin{array}{c}0.0215^{c} \\
(0.0759)\end{array}$ & $\begin{array}{c}0.0186^{c} \\
(0.0834)\end{array}$ \\
\hline Intercept & $\begin{array}{c}-0.60503^{c} \\
(0.0602)\end{array}$ & $\begin{array}{c}-0.64221^{\mathrm{b}} \\
(0.0461)\end{array}$ & $\begin{array}{c}-0.63064^{\mathrm{b}} \\
(0.0496)\end{array}$ \\
\hline Adjusted $\mathrm{R}^{2}$ & 0.4701 & 0.4695 & 0.4586 \\
\hline Number of observations & 2148 & 2148 & 2148 \\
\hline
\end{tabular}

${ }^{a}$ statistical significance at the $1 \%$ level. ${ }^{b}$ statistical significance at the $5 \%$ level. ${ }^{c}$ statistical significance at the $10 \%$ level.

percent increase in control rights over cash flow rights of the largest ultimate owner increases unsigned discretionary accruals by about 4\%. Models 2 and 3 propose an alternative test of $H_{3}$. Two dummy variables are included. The first-control exceeds cash flow rights-takes the value of 1 if the largest ultimate owner control rights are higher than its cash flow rights ad zero otherwise, and the second-control exceeds cash flow rights, high-takes the value of one if the control rights-cash flow rights gap is higher than the median gap and zero otherwise. As such, we could be able to tell if a high separation between ownership and control has a different impact on unsigned discretionary accruals. In model 2, the first dummy variable is included alone and has a positive and statistically significant coefficient, which is consistent with our previous findings in Table 4. In model 3, the two dummies are included jointly. The first has a positive yet not significant coefficient while the second has a positive and statistically 
significant coefficient. The latter result implies that unsigned discretionary accruals are almost $25 \%$ higher in firms where there is an above the average separation between ownership and control. Consistent with our results in Table 4 and Table 6, the cash flow rights variable has a negative and significant coefficient in all models. Overall, the evidence in Table 5 indicates that the magnitude of separation between ownership and control, especially at higher levels, has a positive and significant impact on earnings management activity.

Table 6 reports regression results addressed to test our fourth hypothesis $\left(H_{4}\right)$. We repeat all regressions in Table 5 and include two variables that proxy for the presence and bargaining power of the second ultimate owner, respectively.

Table 6. The effects of the presence and bargaining power of the second ultimate owner on unsigned discretionary accruals.

\begin{tabular}{|c|c|c|c|c|c|c|}
\hline Independent variables & Model 1 & Model 2 & Model 3 & Model 4 & Model 5 & Model 6 \\
\hline Cash flow rights & $\begin{array}{l}-0.0646^{\mathrm{a}} \\
(0.0006)\end{array}$ & $\begin{array}{l}-0.0674^{\mathrm{a}} \\
(0.0003)\end{array}$ & $\begin{array}{l}-0.0644^{\mathrm{a}} \\
(0.0006)\end{array}$ & $\begin{array}{l}-0.0695^{\mathrm{a}} \\
(0.0001)\end{array}$ & $\begin{array}{l}-0.0723^{\mathrm{a}} \\
(0.0001)\end{array}$ & $\begin{array}{l}-0.0696^{\mathrm{a}} \\
(0.0001)\end{array}$ \\
\hline Control minus cash flow rights & $\begin{array}{c}0.0484^{\mathrm{b}} \\
(0.0273)\end{array}$ & & & $\begin{array}{l}0.0454^{\mathrm{b}} \\
(0.0353)\end{array}$ & & \\
\hline Control exceeds cash flow rights dummy & & $\begin{array}{l}0.2197^{\mathrm{a}} \\
(0.0072)\end{array}$ & $\begin{array}{c}0.1231 \\
(0.2297)\end{array}$ & & $\begin{array}{l}0.2094^{\mathrm{a}} \\
(0.0090)\end{array}$ & $\begin{array}{c}0.1137 \\
(0.2659)\end{array}$ \\
\hline Control exceeds cash flow rights, high & & & $\begin{array}{c}0.2035 \\
(0.1190)\end{array}$ & & & $\begin{array}{c}0.1976 \\
(0.1313)\end{array}$ \\
\hline Second ultimate owner dummy & $\begin{array}{l}-0.1141 \\
(0.1851)\end{array}$ & $\begin{array}{l}-0.1435 \\
(0.1059)\end{array}$ & $\begin{array}{l}-0.1313 \\
(0.1394)\end{array}$ & & & \\
\hline $\begin{array}{l}\text { Second ultimate owner control rights over first } \\
\text { ultimate owner control rights }\end{array}$ & & & & $\begin{array}{l}-0.1135^{\mathrm{c}} \\
(0.0899)\end{array}$ & $\begin{array}{l}-0.1335^{c} \\
(0.0550)\end{array}$ & $\begin{array}{l}-0.1317^{\mathrm{c}} \\
(0.0574)\end{array}$ \\
\hline Market-to-book ratio & $\begin{array}{c}0.0018 \\
(0.6045)\end{array}$ & $\begin{array}{c}0.0013 \\
(0.7047)\end{array}$ & $\begin{array}{c}0.0018 \\
(0.5936)\end{array}$ & $\begin{array}{c}0.0017 \\
(0.6171)\end{array}$ & $\begin{array}{c}0.0013 \\
(0.7055)\end{array}$ & $\begin{array}{c}0.0017 \\
(0.6069)\end{array}$ \\
\hline Long-term leverage ratio & $\begin{array}{c}0.1370 \\
(0.1329)\end{array}$ & $\begin{array}{c}0.1424 \\
(0.1177)\end{array}$ & $\begin{array}{c}0.1338 \\
(0.1411)\end{array}$ & $\begin{array}{c}0.1320 \\
(0.1490)\end{array}$ & $\begin{array}{c}0.1352 \\
(0.1395)\end{array}$ & $\begin{array}{c}0.1279 \\
(0.1614)\end{array}$ \\
\hline Log of total assets & $\begin{array}{c}-0.2121^{\mathrm{a}} \\
(0.0001)\end{array}$ & $\begin{array}{l}-0.2114^{\mathrm{a}} \\
(0.0001)\end{array}$ & $\begin{array}{c}-0.2126^{\mathrm{a}} \\
(0.0001)\end{array}$ & $\begin{array}{l}-0.2115^{\mathrm{a}} \\
(0.0001)\end{array}$ & $\begin{array}{c}-0.2106^{\mathrm{a}} \\
(0.0001)\end{array}$ & $\begin{array}{c}-0.2122^{\mathrm{a}} \\
(0.0001)\end{array}$ \\
\hline Absolute difference in ROA & $\begin{array}{c}0.1184 \\
(0.0001)\end{array}$ & $\begin{array}{c}0.1197^{\mathrm{a}} \\
(0.0001)\end{array}$ & $\begin{array}{c}0.1196^{\mathrm{a}} \\
(0.0001)\end{array}$ & $\begin{array}{c}0.1176^{\mathrm{a}} \\
(0.0001)\end{array}$ & $\begin{array}{c}0.1187^{\mathrm{a}} \\
(0.0001)\end{array}$ & $\begin{array}{c}0.1188^{\mathrm{a}} \\
(0.0001)\end{array}$ \\
\hline Negative net income dummy & $\begin{array}{c}0.0236 \\
(0.4148)\end{array}$ & $\begin{array}{c}0.0230 \\
(0.4263)\end{array}$ & $\begin{array}{c}0.0258 \\
(0.3726)\end{array}$ & $\begin{array}{c}0.0229 \\
(0.4272)\end{array}$ & $\begin{array}{c}0.0225 \\
(0.4354)\end{array}$ & $\begin{array}{c}0.0251 \\
(0.3850)\end{array}$ \\
\hline Absolute value of ROA & $\begin{array}{c}0.0186^{c} \\
(0.0951)\end{array}$ & $\begin{array}{c}0.0234 \\
(0.1230)\end{array}$ & $\begin{array}{c}0.0239 \\
(0.1152)\end{array}$ & $\begin{array}{c}0.0253^{c} \\
(0.0819)\end{array}$ & $\begin{array}{c}0.0158^{c} \\
(0.0982)\end{array}$ & $\begin{array}{c}0.0236 \\
(0.0851)\end{array}$ \\
\hline Intercept & $\begin{array}{l}-0.5828^{c} \\
(0.0692)\end{array}$ & $\begin{array}{l}-0.6121^{c} \\
(0.0568)\end{array}$ & $\begin{array}{l}-0.5998^{c} \\
(0.0608)\end{array}$ & $\begin{array}{l}-0.5737^{c} \\
(0.0759)\end{array}$ & $\begin{array}{l}-0.5975^{c} \\
(0.0654)\end{array}$ & $\begin{array}{c}-0.5913^{c} \\
(0.0668)\end{array}$ \\
\hline Adjusted $\mathrm{R}^{2}$ & 0.4677 & 0.4684 & 0.4575 & 0.4660 & 0.4664 & 0.4563 \\
\hline Number of observations & 2148 & 2148 & 2148 & 2148 & 2148 & 2148 \\
\hline
\end{tabular}

${ }^{a}$ statistical significance at the $1 \%$ level. ${ }^{b}$ statistical significance at the $5 \%$ level. ${ }^{c}$ statistical significance at the $10 \%$ level. 
The objective is to document whether the presence and bargaining power of the second ultimate owner contribute to alleviate the earnings management incentives arising from the separation between ownership and control achieved by the largest ultimate owner. The variable of interest in models 1,2 and 3 is the second ultimate owner dummy. This variable's coefficient is negative, yet not statistically significant. The coefficients of the other ultimate ownership variables have similar magnitude and statistical significance as in Table 5, except in model 3 where the control exceeds cash flow rights and the control exceeds cash flow rights, high dummies are not statistically significant. As such, our results provide at best only mild evidence that the presence of a second ultimate owner decreases unsigned discretionary accruals. The variable of interest in models 4, 5 and 6 is the second ultimate owner control rights over first ultimate owner a control right which is our proxy for the second ultimate owner bargaining power vis-à vis the largest ultimate owner. This variable coefficient is negative and statistically significant (at the 10\% level) in all three models. Therefore, our results offer evidence that the bargaining power, not the mere existence, of a second ultimate owner is an effective governance mechanism that limits the incentives of the largest ultimate owner to manipulate earnings arising from the separation between ownership and control.

Table 7 presents the results of six regressions addressed to test our final hypothesis $\left(H_{5}\right)$. Again, the dependent variable is the logarithm of unsigned discretionary accruals. In essence, we augment the regressions in Table 5 by adding a

Table 7. The effects of family ownership on abnormal accruals.

\begin{tabular}{|c|c|c|c|c|c|c|}
\hline Independent variables & Model 1 & Model 2 & Model 3 & Model 4 & Model 5 & Model 6 \\
\hline Cash flow rights & $\begin{array}{l}-0.0745^{\mathrm{a}} \\
(<0.0001)\end{array}$ & $\begin{array}{l}-0.0805^{\mathrm{a}} \\
(<0.0001)\end{array}$ & $\begin{array}{l}-0.0815^{\mathrm{a}} \\
(<0.0001)\end{array}$ & $\begin{array}{l}-0.0847^{a} \\
(<0.0001)\end{array}$ & $\begin{array}{l}-0.0731^{\mathrm{a}} \\
(<0.0001)\end{array}$ & $\begin{array}{l}-0.0861^{\mathrm{a}} \\
(<0.0001)\end{array}$ \\
\hline Control minus cash flow rights & $\begin{array}{c}0.0462^{\mathrm{a}} \\
(0.0023)\end{array}$ & $\begin{array}{c}0.0382^{\mathrm{a}} \\
(0.0021)\end{array}$ & & & & \\
\hline Control exceeds cash flow rights, high & & & $\begin{array}{c}0.1925^{\mathrm{a}} \\
(0.0312)\end{array}$ & $\begin{array}{c}0.2015^{\mathrm{a}} \\
(0.0428)\end{array}$ & $\begin{array}{c}0.1028 \\
(0.3572)\end{array}$ & $\begin{array}{c}0.1182 \\
(0.4195)\end{array}$ \\
\hline Control exceeds cash flow rights, high & & & & & $\begin{array}{c}0.2563^{c} \\
(0.0752)\end{array}$ & $\begin{array}{c}0.2349^{c} \\
(0.0657)\end{array}$ \\
\hline Family & $\begin{array}{c}0.1952^{\mathrm{b}} \\
(0.0413)\end{array}$ & $\begin{array}{c}0.2014^{\mathrm{b}} \\
(0.0486)\end{array}$ & $\begin{array}{c}0.2175^{c} \\
(0.0501)\end{array}$ & $\begin{array}{c}0.1945^{\mathrm{b}} \\
(0.0491)\end{array}$ & $\begin{array}{c}0.2183^{\mathrm{b}} \\
(0.0437)\end{array}$ & $\begin{array}{c}0.1852^{\mathrm{b}} \\
(0.0453)\end{array}$ \\
\hline Cash flow rights $\times$ Family & & $\begin{array}{c}-0.0068^{\mathrm{a}} \\
(0.0012)\end{array}$ & & $\begin{array}{c}-0.0458^{\mathrm{a}} \\
(0.0023)\end{array}$ & & $\begin{array}{c}-0.0058^{\mathrm{a}} \\
(0.0015)\end{array}$ \\
\hline (Control minus Cash flow rights) $\times$ Family & & $\begin{array}{c}0.0051^{\mathrm{a}} \\
(0.0034)\end{array}$ & & & & \\
\hline (Control exceeds Cash flow rights dummy) $\times$ Family & & & & $\begin{array}{c}0.0194^{\mathrm{b}} \\
(0.0384)\end{array}$ & & $\begin{array}{c}0.0154^{c} \\
(0.0915)\end{array}$ \\
\hline (Control exceeds Cash flow rights, high) $\times$ Family & & & & & & $\begin{array}{c}0.0286^{c} \\
(0.0752)\end{array}$ \\
\hline
\end{tabular}




\begin{tabular}{|c|c|c|c|c|c|c|}
\hline Market-to-book ratio & $\begin{array}{c}0.0211^{c} \\
(0.0537)\end{array}$ & $\begin{array}{c}0.0194^{c} \\
(0.0586)\end{array}$ & $\begin{array}{c}0.01829^{c} \\
(00519)\end{array}$ & $\begin{array}{c}0.01946^{\mathrm{b}} \\
(0.0431)\end{array}$ & $\begin{array}{c}0.0173^{c} \\
(0.0618)\end{array}$ & $\begin{array}{c}0.0143^{c} \\
(0.0692)\end{array}$ \\
\hline Long-term leverage ratio & $\begin{array}{c}0.1495^{c} \\
(0.0813)\end{array}$ & $\begin{array}{c}0.1739^{c} \\
(0.0746)\end{array}$ & $\begin{array}{c}0.1532^{c} \\
(0.0825)\end{array}$ & $\begin{array}{c}0.1439^{c} \\
(0.0761)\end{array}$ & $\begin{array}{c}0.1826^{c} \\
(0.0862)\end{array}$ & $\begin{array}{c}0.1731^{\mathrm{c}} \\
(0.0792)\end{array}$ \\
\hline Log of total assets & $\begin{array}{l}-0.2145^{\mathrm{a}} \\
(0.0001)\end{array}$ & $\begin{array}{c}-0.2167^{\mathrm{a}} \\
(0.0001)\end{array}$ & $\begin{array}{l}-0.2201^{\mathrm{a}} \\
(0.0001)\end{array}$ & $\begin{array}{c}-0.2187^{\mathrm{a}} \\
(0.0001)\end{array}$ & $\begin{array}{l}-0.2123^{\mathrm{a}} \\
(0.0001)\end{array}$ & $\begin{array}{c}-0.2119^{\mathrm{a}} \\
(0.0001)\end{array}$ \\
\hline Absolute difference in net income & $\begin{array}{c}0.1583^{\mathrm{a}} \\
(0.0001)\end{array}$ & $\begin{array}{c}0.1438^{\mathrm{a}} \\
(0.0001)\end{array}$ & $\begin{array}{c}0.1574^{\mathrm{a}} \\
(0.0001)\end{array}$ & $\begin{array}{l}0.14462^{\mathrm{a}} \\
(0.0001)\end{array}$ & $\begin{array}{c}0.1479^{a} \\
(0.0001)\end{array}$ & $\begin{array}{c}0.1537^{\mathrm{a}} \\
(0.0001)\end{array}$ \\
\hline Negative net income dummy & $\begin{array}{c}0.0375 \\
(0.2138)\end{array}$ & $\begin{array}{c}0.0361 \\
(0.2687)\end{array}$ & $\begin{array}{c}0.0345 \\
(0.2461)\end{array}$ & $\begin{array}{c}0.0358 \\
(0.2315)\end{array}$ & $\begin{array}{c}0.0345 \\
(0.2649)\end{array}$ & $\begin{array}{c}0.0386 \\
(0.2492)\end{array}$ \\
\hline Absolute value of ROA & $\begin{array}{c}0.0219^{c} \\
(0.0912)\end{array}$ & $\begin{array}{c}0.0253^{c} \\
(0.0937)\end{array}$ & $\begin{array}{c}0.0274^{c} \\
(0.0877)\end{array}$ & $\begin{array}{c}0.0236^{c} \\
(0.0769)\end{array}$ & $\begin{array}{c}0.0296^{c} \\
(0.0816)\end{array}$ & $\begin{array}{c}0.0276^{c} \\
(0.0877)\end{array}$ \\
\hline Intercept & $\begin{array}{l}-0.8523^{c} \\
(0.0514)\end{array}$ & $\begin{array}{l}-0.6489^{c} \\
(0.0922)\end{array}$ & $\begin{array}{c}-0.7291^{\mathrm{c}} \\
(0.0739)\end{array}$ & $\begin{array}{l}-0.8001^{c} \\
(0.0821)\end{array}$ & $\begin{array}{l}-0.9132^{c} \\
(0.0751)\end{array}$ & $\begin{array}{l}-0.8421^{c} \\
(0.0825)\end{array}$ \\
\hline Adjusted $\mathrm{R}^{2}$ & 0.4459 & 0.4578 & 0.4489 & 0.4509 & 0.4523 & 0.4673 \\
\hline Number of observations & 2148 & 2148 & 2148 & 2148 & 2148 & 2148 \\
\hline
\end{tabular}

${ }^{a}$ statistical significance at the $1 \%$ level. ${ }^{b}$ statistical significance at the $5 \%$ level. ${ }^{c}$ statistical significance at the $10 \%$ level.

1) dummy variable indicating family control, and 2) interaction variables between the family dummy and the cash flow rights and separation between ownership of the largest ultimate owner variables. In models 1, 3, and 5, the family dummy is added alone. Its coefficient is positive and statistically significant in all models. The effect of family control on unsigned discretionary accruals is also economically significant. For instance, under model 1, the results imply that unsigned discretionary accruals are $21.5 \%$ higher in family controlled firms. In models 2, 4 and6, we add the family dummy along with interactions between the family dummy and the cash flow rights and separation between ownership and control variables. The objective is to document whether families have more incentives to manage earnings than other types of ultimate owners. Again, under models 2, 4 and6, the family dummy has a positive ad statistically significant coefficient. The Cash flow rights $\times$ Family interaction variable have a negative and statistically significant, while the (Control minus Cash flow rights) $\times$ Family, (Control exceeds Cash flow rights dummy) $\times$ Family, and (Control exceeds Cash flow rights, high) $\times$ Family interaction variables have positive and statistically significant coefficients. Thus, our results suggest that while families have similar incentives to manage earnings, their incentives outsize those of other types of ultimate owners.

\section{Conclusion}

In this paper, we investigate the relation between earnings management and corporate governance in Canada. We build on the literature, mostly conducted in the U.S, which advocates that earnings management is an agency cost of 
separating ownership from control (e.g., Warfield, Wild and Wild, 1995; and Gadhoum, 2015). However, we note that outside the U.S, the separation between ownership and control is mainly achieved by large shareholders, not professional managers which may lead to different and potentially larger agency costs than in the U.S (Bebchuk, Kraakman and Triantis, 2000; Li and Thibodeau, 2019).

Our findings indicate that earnings management activity is higher in firms controlled through pyramidal structures and multiple classes of shares. Moreover, earnings management activity is positively related to the separation between ownership and control (especially at higher levels) achieved by the largest ultimate owner. These results are consistent with the hypothesis that the separation between ownership and control in the hands of large shareholders distorts their incentives toward generating private benefits and manipulating accounting numbers as a way to mask these private benefits.

Our results also indicate that earnings management activity decreases with the share of cash flow rights of the largest ultimate owner, which is consistent with the hypothesis that an increase in cash flow rights gives large shareholders more incentives to monitor opportunistic earnings management that could have adverse effects on their wealth.

We suggest that not all governance mechanisms (such as boards of directors, audit committees, institutional investors) may be able to inhibit large shareholders incentives to manage earnings. Instead, we focus on a particular governance mechanism, multiple large shareholders that we believe to be effective in an environment characterized by concentrated ownership. We find that a second ultimate owner with sufficient bargaining power is able to reduce earnings management incentives of the largest ultimate owner.

Finally, we find that earnings management activity is significantly higher in family controlled firms. This finding is consistent with the hypothesis that families are more likely to manage earnings to mask their extra private benefits and to preserve their reputation.

While the previous results are important especially by showing that not only the ownership concentration affects the earnings management but the two largest ultimate shareholders play also a particular role in reducing the abuse of the Management. Nevertheless, this paper didn't show evidence that if the largest owners are also in the Management Team, they could use private benefits such as amenities, political connections and other benefits if they own other companies and could benefit from outsourcing. Besides, the conclusion here needs to be taken with caution and prudence until further research in other countries and/or with a larger sample could be conducted. Needless to say that the more research in this area the more conclusive will be the findings because there is a huge controversy and dilemma about the computation of accruals.

\section{Acknowledgements}

I wish to express my gratitude to Sadok El Ghoul for his great input through the Social science and humanity council of Canada. He has made many useful and 
valuable comments, suggestions and corrections concerning previous versions which have significantly improved this manuscript. Special thanks to the anonymous reviewers for their constructive comments.

This paper was partially written during my tenure at PMU.

\section{Conflicts of Interest}

The author declares no conflicts of interest regarding the publication of this paper.

\section{References}

Ahmed, A. S., Lobo, G. J., \& Zhou, J. (2000). Job Security and Income Smoothing: An Empirical Test of the Fudenberg and Tirole (1995) Model. Syracuse University Working Paper.

Alharbi, S., Atawnah, N., Al Mamun, M., \& Jahangir, M. A. (2020). Local Culture and Tax Avoidance: Evidence from Gambling Preference Behaviour. Global Finance Journal, Article ID: 100585. https://doi.org/10.1016/j.gfj.2020.100585

Alharbi, S., Mamun, M., \& Atawnah, N. (2021). Uncovering Real Earnings Management: Pay Attention to Risk-Taking Behavior. International Journal of Financial Studies, 9, 53. https://doi.org/10.3390/ijfs9040053

Anderson, R. C., Mansi, S. A., \& Reeb, D. M. (2003). Founding Family Ownership and the Agency Cost of Debt. Journal of Financial Economics, 68, 263-285. https://doi.org/10.1016/S0304-405X(03)00067-9

Attig, N., Fischer, K., \& Gadhoum, Y. (2003). On the Determinants of Pyramidal Ownership: Evidence on Dilution of Minority Interests. University of Quebec at Montreal Working Paper.

Attig, N., Fong, W. M., Gadhoum, Y., \& Lang, L. H. P. (2006). Effects of Large Shareholdings on Information Asymmetry and Stock Liquidity. Journal of Banking and Finance, 30, 2875-2892. https://doi.org/10.1016/j.jbankfin.2005.12.002

Badolato, P. G., Donelson, D C., \& Ege, M. (2014). Audit Committee Financial Expertise and Earnings Management: The Role of Status. Journal of Accounting and Economics, 58, 208-230. https://doi.org/10.1016/j.jacceco.2014.08.006

Bae, K.-H., Kang, J.-K., \& Kim, J.-M. (2002). Tunneling or Value Added? Evidence from Mergers by Korean Business Groups. Journal of Finance, 57, 2695-2740. https://doi.org/10.1111/1540-6261.00510

Baker, T. A., Lopez, T. J., Reitenga, A. L., \& Ruch, G. W. (2019). The Influence of CEO and CFO Power on Accruals and Real Earnings Management. Review of Quantitative Finance and Accounting, 52, 325-345. https://doi.org/10.1007/s11156-018-0711-Z

Bebchuk, L. A., Kraakman, R., \& Triantis, G. (2000). Stock Pyramids, Cross-Ownership, and Dual Class Equity. In R. Morck (Ed.), Concentrated Corporate Ownership. University of Chicago Press.

Bennedsen, M., \& Wolfenzon, D. (2000). The Balance of Power in Closely Held Corporations. Journal of Financial Economics, 58, 113-139. https://doi.org/10.1016/S0304-405X(00)00068-4

Bertrand, M., Mehta, P., \& Mullainathan, S. (2002). Ferreting out Tunneling: An Application to Indian Business Groups. Quarterly Journal of Economics, 117, 121-148. https://doi.org/10.1162/003355302753399463

Bhide, A. (1993). The Hidden Costs of Stock Market Liquidity. Journal of Financial Eco- 
nomics, 34, 31-51. https://doi.org/10.1016/0304-405X(93)90039-E

Burgstahler, D., \& Dichev, I. (1999). Earnings Management to Avoid Earnings Decreases and Losses. Journal of Accounting and Economics, 24, 99-126. https://doi.org/10.1016/S0165-4101(97)00017-7

Cheng, Q., Lee, J., \& Shevlin, T. (2016). Internal Governance and Real Earnings Management. The Accounting Review, 91, 1051-1085. https://doi.org/10.2308/accr-51275

Chung, R., Firth, M., \& Kim, J.-B. (2002). Institutional Monitoring and Opportunistic Earnings Management. Journal of Corporate Finance, 8, 29-48. https://doi.org/10.1016/S0929-1199(01)00039-6

Claessens, S., Djankov, S., \& Lang, L. H. P. (2000). The Separation of Ownership and Control in East Asian Corporations. Journal of Financial Economics, 58, 81-112. https://doi.org/10.1016/S0304-405X(00)00067-2

Claessens, S., Djankov, S., Fan, J. P. H., \& Lang, L. H. P. (2002). Ddisentangling the Incentive and Entrenchment Effects of Large Shareholdings. Journal of Finance, 57, 2741-2771. https://doi.org/10.1111/1540-6261.00511

DeAngelo, L. E. (1988). Managerial Competition, Information Costs, and Corporate Governance: The Use of Accounting Performance Measures in Proxy Contests. Journal of Accounting and Economics, 10, 3-36. https://doi.org/10.1016/0165-4101(88)90021-3

Dechow, P. M., Sloan, R. G., \& Sweeney, A. P. (1996). Causes and Consequences of Earnings Manipulation: An Analysis of Firms Subject to Enforcement Actions by the SEC. Contemporary Accounting Research, 13, 1-36. https://doi.org/10.1111/j.1911-3846.1996.tb00489.x

DeFond, M. L., \& Jiambalvo, J. (1994). Debt Covenant Violation and Manipulation of Accruals. Journal of Accounting and Economics, 17, 145-176. https://doi.org/10.1016/0165-4101(94)90008-6

DeFond, M. L., \& Park, C. W. (1997). Smoothing Income in Anticipation of Future Earnings. Journal of Accounting and Economics, 23, 115-139. https://doi.org/10.1016/S0165-4101(97)00004-9

Demsetz, H., \& Lehn, K. (1985). The Structure of Corporate Ownership: Causes and Consequences. Journal of Political Economy, 93, 1155-1177. https://doi.org/10.1086/261354

Dou, Y., Khan, M., \& Zou, Y. (2016). Labor Unemployment Insurance and Earnings Management. Journal of Accounting and Economics, 61, 166-184. https://doi.org/10.1016/j.jacceco.2015.06.001

Du, Q., \& Shen, R. (2018). Peer Performance and Earnings Management. Journal of Banking \& Finance, 89, 125-137. https://doi.org/10.1016/j.jbankfin.2018.01.017

Easterwood, C. M. (1997). Takeovers and Incentives for Earnings Management: An Empirical Analysis. Journal of Applied Business Research, 14, 29-48. https://doi.org/10.19030/jabr.v14i1.5726

Erickson, M., \& Wang, S.-W. (1999). Earnings Management by Acquiring Firms in Stock for Stock Mergers. Journal of Accounting and Economics, 27, 149-176. https://doi.org/10.1016/S0165-4101(99)00008-7

Faccio, M. (2004). Politically Connected Firms.

Faccio, M., \& Lang, L. H. P. (2002). The Ultimate Ownership of Western European Corporations. Journal of Financial Economics, 65, 365-395. https://doi.org/10.1016/S0304-405X(02)00146-0

Francis, D. (1986). Controlling Interest: Who Owns Canada. Macmillan of Canada.

Fudenberg, D., \& Tirole, J. (1995). A Theory of Income and Dividend Smoothing Based 
on Incumbency Rents. Journal of Political Economy, 103, 75-93.

https://doi.org/10.1086/261976

Gadhoum, Y. (2015). International Comparison of Ownership Structures and Expropriation of Listed Firms. International Journal of Advanced Research, 3, 124-135.

Gadhoum, Y. (2016). Ownership Structure, Corporate and Dividend Pay-Out in Canada. Asia Pacific Journal of Advanced Business and Social Studies, 2, 31-52.

Gadhoum, Y., Gueyie, J. P., \& Bergeron, M. (2007). Family Ownership Structure. Journal of Corporate Ownership and Control, 4, 132-141. https://doi.org/10.22495/cocv4i4p12

Gomes, A., \& Novaes, W. (1999). Multiple Large Shareholders in Corporate Governance. Rodney L. White Center for Financial Research Working Paper.

Haga, J., Höglund, H., \& Sundvik, D. (2018). Stock Market Listing Status and Real Earnings Management. Journal of Accounting and Public Policy, 37, 420-435. https://doi.org/10.1016/j.jaccpubpol.2018.09.002

Haw, I.-M., Hu, B., Hwang, L.-S., \& Wu, W. (2004). Ultimate Ownership, Income Management, and Legal and Extra-Legal Institutions. Journal of Accounting Research, 42, 423-462. https://doi.org/10.1111/j.1475-679X.2004.00144.x

Healy, P. M. (1985). The Effect of Bonus Schemes on Accounting Decisions. Journal of Accounting and Economics, 7, 85-107. https://doi.org/10.1016/0165-4101(85)90029-1

Healy, P. M., \& Whalen, J. M. (1999). A Review of the Earnings Management Literature and Its Implications for Standard Setting. Accounting Horizons, 13, 365-383. https://doi.org/10.2308/acch.1999.13.4.365

Holthausen, R. W., Larcker, D. F., \& Sloan, R. G. (1995). Annual Bonus Schemes and the Manipulation of Earnings. Journal of Accounting and Economics, 19, 29-74. https://doi.org/10.1016/0165-4101(94)00376-G

Jiang, F., Ma, Y., \& Wang, X. (2020). Multiple Blockholders and Earnings Management. Journal of Corporate Finance, 64, Article ID: 101689. https://doi.org/10.1016/j.jcorpfin.2020.101689

Jones, S. (2018). Special Issue on Earnings Management. Abacus, 54, 133-135. https://doi.org/10.1111/abac.12129

Kama, I., \& Melumad, N. (2020). Camouflaged Indicators of Earnings Management. European Accounting Review, 29, 361-382. https://doi.org/10.1080/09638180.2019.1595693

Kasznik, R. (1999). On the Association between Voluntary Disclosure and Earnings Management. Journal of Accounting Research, 37, 57-81. https://doi.org/10.2307/2491396

Khanna, T., \& Rivkin, J. W. (2001). Estimating the Performance Effects of Business Groups in Emerging Markets. Strategic Management Journal, 22, 45-74. https://doi.org/10.1002/1097-0266(200101)22:1<45::AID-SMJ147>3.0.CO;2-F

Klein, A. (2002). Audit Committee, Board of Director Characteristics, and Earnings Management. Journal of Accounting and Economics, 33, 375-400. https://doi.org/10.1016/S0165-4101(02)00059-9

Kontesa, M., Brahmana, R., \& Tong, A. H. H. (2021). Narcissistic CEOs and Their Earnings Management. Journal of Management \& Governance, 25, 223-249. https://doi.org/10.1007/s10997-020-09506-0

Kothari, S. P., Leone, A. J., \& Wasley, C. E. (2005). Performance Matched Discretionary Accrual Measures. Journal of Accounting and Economics, 39, 163-197.

https://doi.org/10.1016/j.jacceco.2004.11.002 
La Porta, R., Lopez-de-Silanes, F., \& Shleifer, A. (1999). Corporate Ownership around the World. Journal of Finance, 54, 471-517. https://doi.org/10.1111/0022-1082.00115

Leuz, C., Nanda, D., \& Wysocki, P. D. (2003). Earnings Management and Investor Protection: An International Comparison. Journal of Financial Economics, 69, 505-527. https://doi.org/10.1016/S0304-405X(03)00121-1

Li, Z. F., \& Thibodeau, C. (2019). CSR-Contingent Executive Compensation Incentive and Earnings Management. Sustainability, 11, 3421. https://doi.org/10.3390/su11123421

Lim, M., How, J., \& Verhoeven, P. (2014). Corporate Ownership, Corporate Governance Reform and Timeliness of Earnings: Malaysian Evidence. Journal of Contemporary Accounting and Economics, 10, 32-45. https://doi.org/10.1016/j.jcae.2013.11.001

Lins, K. V. (2003). Equity Ownership and Firm Value in Emerging Markets. Journal of Financial and Quantitative Analysis, 38, 159-184. https://doi.org/10.2307/4126768

Louis, H. (2004). Earnings Management and the Market Performance of Acquiring Firms. Journal of Financial Economics, 74, 121-148. https://doi.org/10.1016/j.jfineco.2003.08.004

Makarem, N., \& Roberts, C. (2020). Earnings Management to Avoid Earnings Boosts. Journal of Applied Accounting Research, 21, 657-676. https://doi.org/10.1108/JAAR-01-2019-0012

Morck, R. K., Strangeland, D. A., \& Yeung, B. (2000). Inherited Wealth, Corporate Control, and Economic Growth: The Canadian Disease? In R. Morck (Ed.), Concentrated Corporate Ownership. University of Chicago Press. https://doi.org/10.7208/chicago/9780226536828.001.0001

Nenova, T. (2003). The Value of Corporate Voting Rights and Control: A Cross-Country Analysis. Journal of Financial Economics, 68, 325-351. https://doi.org/10.1016/S0304-405X(03)00069-2

Newey, W. K., \& West, K. D. (1987). A Simple, Positive Semi-Definite, Heteroskedasticity and Autocorrelation Consistent Covariance Matrix. Econometrica, 55, 703-708. https://doi.org/10.2307/1913610

Park, Y. W., \& Shin, H.-H. (2004). Board Composition and Earnings Management in Canada. Journal of Corporate Finance, 10, 431-457. https://doi.org/10.1016/S0929-1199(03)00025-7

Payne, J. L., \& Robb, S. W. (2000). Earnings Management: The Effect of Ex Ante Earnings Expectations. Journal of Accounting, Auditing and Finance, 15, 371-392. https://doi.org/10.1177/0148558X0001500401

Perry, S. E., \& Williams, T. H. (1994). Earnings Management Preceding Management Buyout Offers. Journal of Accounting and Economics, 18, 157-179. https://doi.org/10.1016/0165-4101(94)00362-9

Rangan, S. (1998). Earnings Management and the Performance of Seasoned Equity Offerings. Journal of Financial Economics, 50, 101-122. https://doi.org/10.1016/S0304-405X(98)00033-6

Slovin, M. B., \& Sushka, M. E. (1993). Ownership Concentration, Corporate Control Activity, and Firm Value: Evidence from the Death of Inside Blockholders. Journal of Finance, 48, 1293-1321. https://doi.org/10.1111/j.1540-6261.1993.tb04755.x

Teoh, S. H., Welch, I., \& Wong, T. J. (1998a). Earnings Management and the Long-Run Market Performance of Initial Public Offerings. Journal of Finance, 53, 1935-1974. https://doi.org/10.1111/0022-1082.00079

Teoh, S. H., Welch, I., \& Wong, T. J. (1998b). Earnings Management and the Underper- 
formance of Seasoned Equity Offerings. Journal of Financial Economics, 50, 63-99.

Warfield, T. D., Wild, J. J., \& Wild, K. L. (1995). Managerial Ownership, Accounting Choices, and Informativeness of Earnings. Journal of Accounting and Economics, 20, 61-91. https://doi.org/10.1016/0165-4101(94)00393-J

Xie, B., Davidson III, W. N., \& DaDalt, P. J. (2003). Earnings Management and Corporate Governance: The Role of the Board and the Audit Committee. Journal of Corporate Finance, 9, 295-316. https://doi.org/10.1016/S0929-1199(02)00006-8 